\title{
Agents of Institutional Change in EU Policy The Social Investment Moment
}

\author{
de la Porte, Caroline; Natali, David
}

Document Version

Accepted author manuscript

Published in:

Journal of European Public Policy

DOI:

10.1080/13501763.2017.1401110

Publication date:

2018

License

Unspecified

Citation for published version (APA):

de la Porte, C., \& Natali, D. (2018). Agents of Institutional Change in EU Policy: The Social Investment Moment. Journal of European Public Policy, 25(6), 828-843. https://doi.org/10.1080/13501763.2017.1401110

Link to publication in CBS Research Portal

\section{General rights}

Copyright and moral rights for the publications made accessible in the public portal are retained by the authors and/or other copyright owners and it is a condition of accessing publications that users recognise and abide by the legal requirements associated with these rights.

Take down policy

If you believe that this document breaches copyright please contact us (research.lib@cbs.dk) providing details, and we will remove access to the work immediately and investigate your claim. 


\section{Agents of Institutional Change in EU Policy: The Social Investment Moment}

\section{Caroline de la Porte and David Natali}

Journal article (Accepted version)

Cite: Agents of Institutional Change in EU Policy : The Social Investment Moment. / de la Porte, Caroline; Natali, David. In: Journal of European Public Policy, Vol. 25, No. 6, 2018, p. 828-843.

This is an Accepted Manuscript of an article published by Taylor \& Francis in Journal of European Public Policy on 22 March 2018, available online:

https://www.tandfonline.com/doi/full/10.1080/13501763.2017.1401110 
Agents of Institutional Change in

EU Policy: The Social Investment Moment ${ }^{\mathrm{i}}$

\section{Caroline de la Porte and David Natali}

Note : This is the pre-print version of the article that has appeared in the Journal of European Public Policy 25(6). The final version can be read and downloaded here : https://www.tandfonline.com/doi/full/10.1080/13501763.2017.1401110

50 free pre-prints available for those who do not have library access : https://www.tandfonline.com/eprint/azp6HTIwyxwUTmubqWIV/full

\section{Abstract}

The contribution addresses - through actor-centred historical institutionalism - why and how social investment (SI) emerged at the European Union level. SI policies built on the institutional basis of the policy coordination processes in employment and social inclusion, which originated in the late 1990s and early 2000s. The pre-existent processes represented the necessary but not sufficient condition for the EU SIP to materialize. The decisive factor was the activity of three types of entrepreneurs - intellectual, bureaucratic and political - that enabled the crystallization of the EU Social Investment package (SIP) through issue framing, institutional alignment and consensusbuilding. Despite this, the SIP of 2013 ended as a 'social investment moment' that rapidly lost momentum because no additional measures such as indicators or funds were integrated with SIP. Furthermore, the Commission's political priorities changed and the key entrepreneurs that had been active for the materialization of the SIP were no longer centre stage. The continued presence of former influential entrepreneurs in the EU policy arena, although in different roles, may enable integration of EU SI into new EU social policy initiatives.

Keywords: actor-centred institutionalism, European Union, EU social policy, historical institutionalism, policy entrepreneur, social investment 


\section{INTRODUCTION}

In 2013, the European Union (EU) adopted a 'Social Investment Package' (SIP) centred on policies to invest in human capital throughout the life-course. This contribution is interested in why and how social investment (SI) policy developed at EU level, focusing on the role of agents of institutional change. In the literature, such actors are referred to as 'policy entrepreneurs' (Kingdon 1995), or 'ideational leaders' (Stiller 2010), who create policy agendas and make decisions on new policy. This study unpacks this broad range of actors, identifying three ideal-type agents that mobilise different power resources during the policy process. The first type is the 'intellectual entrepreneur', whose resource is knowledge and who is typically active prior to and in the early phases of agenda-setting. The second type is the 'bureaucratic entrepreneur', whose resource is access to institutional opportunities, and who is central between agenda-setting and decision-making in transposing knowledge to a particular institutional setting. The third type is the 'political entrepreneur', whose resource is political power, and who is directly or indirectly involved in decision-making.

Applying this actor-based historical institutional framework, we found that SIP, consisting of soft-law initiatives, was adopted due to the combined activity of the three types of entrepreneurs. However, SI lost momentum when the entrepreneurs involved in its development were no longer centrally present in the EU social policy arena. Even so, the former institutional base of SI, rooted in the European Employment Strategy (EES) from the late 1990s and the social inclusion Open Method of Coordination (OMC) from the early 2000s, is still present. Furthermore, the persistent activism of some leading figures, although no longer as central entrepreneurs, contributes to maintaining some focus on SI in the context of the European Pillar of Social Rights (EPSR).

The remainder of this paper is organised as follows: the following section presents a literature review, the theoretical and analytical actor-based analytical framework, as well as the methodology. The subsequent section consists of the analysis of SI institutionalisation, in four temporal stages. The final section discusses and concludes. 


\section{LITERATURE REVIEW, THEORY AND ANALYTICAL FRAMEWORK}

\section{Literature Review}

The EU's initial response to the crisis - including a Memoranda of Understanding for countries unable to repay their debt without financial support - was one of austerity. The countries under such coercive arrangements have been forced to 'implement pretty much the same deeply unpopular (...) austerity package' (Armingeon and Baccaro 2012: 275). In parallel, the EU governance was revised, emphasising cost containment and budgetary control, in order to prevent sovereign debt crises in the future (de la Porte and Heins 2015). Governance of both economic and social policies is now centralised in the European Semester.

While considerable attention has been paid to alterations in the governance of the EU (Scharpf 2013; Verdun 2015), there have been less contributions on EU employment and social policy (Crespy and Menz 2015). Some scholars have argued that SI emerged as a positive narrative in a context marked by austerity (Ferrera 2016; Hemerijck 2015). Indeed, trust in the EU decreased rapidly following the EU's austerity policy: it was 32 per cent in 2012 (compared to 57 per cent in 2007). Similarly, the percentage of Europeans that had a positive image of the EU in the first half of 2007 was 52 per cent, contrasting with 30.5 per cent in 2012 and in 2013 (EU 2016). In this vein, Hemerijck (2015 xiii) underscored that: 'The paramount importance of the 2013 Social Investment Package is that it officially endorses a socially inclusive and economically robust alternative to the less coherent fiscal austerity orthodoxy cum monetarist heterodoxy policy mix.' Ferrera (2016) analysed the discursive and capacity-building potential of SI, concluding that the discourse has not been influential at national level following the adoption of the EU's Social Investment Package (SIP). Zeitlin and Vanhercke (2017) examined the 'socialisation' of the European Semester through a framework based on learning in the Commission. Their findings suggest that the EU's social dimension is very strong. 
While these works have made important contributions, they have not considered the role of agents in a longitudinal and institutional analysis of the genesis of SI at EU level. This contribution analyses why, how, under which political conditions, and in which institutional setting, the SIP emerged. The agency-based historical institutionalist perspective highlights that SIP emerged because there was a pre-existent institutional base, but also because various entrepreneurs mobilised through a combination of different power resources. It also shows the limit of entrepreneurial activity: even when consensus is obtained that enables a decision on a policy, it can quickly disappear from the agenda again, when political conditions are not favourable. This is particularly the case for soft law - such as SI - that is not strongly institutionalised. From a theoretical-analytical perspective, our study shows why, when, and how agents matter in institutional change. It also conceptualises 'policy entrepreneurs' precisely, enabling applicability of this framework to other studies of policy alteration.

\section{Theory, Analytical Framework and Methodology}

This contribution develops a theory to capture when agents are influential in a longer process of bounded institutional change (Pierson 1996; Mahoney and Thelen 2010). Time is conceptualised in inductively derived temporal 'stages', during which there is significant institutional development (de la Porte 2008). For our case, institutional change (in 'stages') can be located in Commission communications and recommendations, European Council Conclusions, treaty changes, changed governance structures, or core quantitative indicators representing a policy frame. In each stage, change is gradual, through displacement, layering, drift, and conversion (Streeck and Thelen 2005).

In this paper, we do not ex ante associate agents with a type of change (Mahoney and Thelen 2010). Instead, the analytical approach ties in the role of actors with institutional change dynamically, by building on 'policy entrepreneurship'. Thus, two main shortcomings in the literature are addressed - that is, the vague definition of actors and of their activities. Policy entrepreneurs are crucial in a process of institutional change, as they are capable, inter alia, of identifying problems and finding 
solutions, advocating new ideas and mobilising political support and public opinion. They are considered as a broad category of actors who are 'in or out of government, in elected or appointed positions, in interest groups or research organizations' (Kingdon 1995). In Table 1, we specify three types of entrepreneur according to the arena in which they operate and, by implication, their main power resources. We also present the different types of activities they can engage in.

Table 1. Policy entrepreneurs and their activities

\begin{tabular}{|c|c|c|c|}
\hline & \multicolumn{3}{|c|}{ Type of Entrepreneur } \\
\hline $\begin{array}{c}\text { Entrepreneur } \\
\text { Activities }\end{array}$ & Intellectual & Bureaucratic & Political \\
\hline $\begin{array}{l}\text { Issue- } \\
\text { framing }\end{array}$ & +++ & ++ & + \\
\hline $\begin{array}{l}\text { Insitutional } \\
\text { alignment }\end{array}$ & + & +++ & +++ \\
\hline $\begin{array}{l}\text { Consensus- } \\
\text { seeking }\end{array}$ & + & + & +++ \\
\hline
\end{tabular}

Source: Author's own elaboration

+++ Strong activity

++ Some activity

+ Little activity

A 'political entrepreneur' is a politically appointed or politically elected individual who has a legal mandate to directly or indirectly engage in decision-making. A 'bureaucratic entrepreneur' is located in the bureaucracy, such as in the European Commission or in a ministry, where policies are prepared. While bureaucrats undertake and organise preparatory work around an issue, bureaucratic entrepreneurs mobilise resources to enable the adoption of policy, in close collaboration with decision-makers. Bureaucratic entrepreneurs can also mobilise external input to increase the likelihood of a decision on a particular policy issue. This includes appointing academics and others 
to provide policy advice and input. An 'intellectual entrepreneur' is a prominent academic or expert, who is appointed to undertake an analysis or to provide policy recommendations on specific issues ${ }^{\mathrm{ii}}$.

Concerning the types of activities actors can engage in, Heclo (1974) focused on 'puzzling' and 'powering'; Mintrom and Norman (2009) considered activities such as problem-definition and team building; while Stiller (2010) explored ideational, as well as communicative and relational, activities. The literature on policy decisions has typically focused on the stages of the policy cycle, from agendasetting through to decision-making. Building on this, this paper works with three broad categories of activities that entrepreneurs engage in: 'issue-framing', 'institutional alignment', and 'consensusseeking'. Issue framing includes activities that frame a policy problem, locating evidence to support a particular frame, developing indicators, and envisaging policy solutions. Institutional alignment consists of adapting a policy solution to the relevant institutional setting, including team building. Consensus-seeking involves seeking alliances, 'powering', as well as decision-making. The timing of issue-framing, institutional alignment, and consensus-building may partially overlap, and various entrepreneurs may be involved in different activities. Moreover, entrepreneurs may persist in the broad arena - here, EU social policy - over long time periods. This often happens through 'revolving doors' that allow actors to move from one position and affiliation to another within a particular policy arena.

Methodologically, the examination involves process-tracing; that is, specifying the "process whereby relevant variables have an effect' within a case (Hall 2008: 23). This combines an inductive approach - for identifying significant moments of institutional change - with a causal-analytical framework - to analyse which constellations of actors are involved in institutional change. The contribution identifies key variables or combinations of variables, focusing on activities of actors, that explain a case (here stage). In each 'stage' we follow the activities of entrepreneurs. Thereby, we intend to shed light on the conditions under which their role is significant for institutional change (Trampusch and Palier 2015: 15). In our conceptualisation, the role of three distinct, individual 
entrepreneurs is analysed. Political conditions are crucial intervening variables for the persistence and strength of institutional change.

For each stage, data sources are triangulated to provide a cross-data validity check. The primary data comprises official documentation from the Commission, minutes of meetings of relevant expert groups and conclusions of the European Council, all of which are publicly available. In addition, 10 in-depth semi-structured expert interviews with key actors involved in the genesis of EU SI have been conducted. The interviewees were selected to represent intellectuals, bureaucrats, and political actors involved in the process under scrutiny. This includes six actors that we have identified as political, intellectual or bureaucratic entrepreneurs, as well as four actors involved in the political and bureaucratic context, but that did not have an entrepreneurial role.

\section{ANALYSIS}

Each stage examines the issue-framing, institutional alignment, and consensus-building activities of the relevant entrepreneurs in institutional change. Stages 1 and 2, respectively, present the emergence and drift of SI initiatives in EU social policy. Stage 3 - which covers a shorter time period - analyses the activities related to SI itself in detail. Stage 4 provides a preliminary analysis of how SI is integrated into the EPSRs.

\section{Stage 1: 1997-2003: Institutional creation of employment and social inclusion coordination}

Stage 1 comprises the institutional creation of the EES and the social inclusion OMC in terms of policy aims and governance procedure. This is the basis on which SI was later built, during stage 3 .

Allan Larsson was influential in the creation of the EES, first as a political entrepreneur and then as a bureaucratic entrepreneur. Larsson's ideas were shaped by those of Meidner and Rhen, Nordic economists, who highlighted the role of labour market policies as a bridge between social and 
economic policies that should contribute to economic growth and fair distribution In the early 1990s, Larsson had mobilised a common employment policy for Europe in the party of European socialists when he was head of the Swedish socialist party - that is, as a political entrepreneur. He became director general for the directorate general of employment and social affairs (DG EMPL) - becoming a central figure in the EU's bureaucracy - in 1995, which enabled him to adapt his policy vision to the EU institutional setting. When he was a bureaucratic entrepreneur, he framed 'social protection as a productive factor', which formed the basis for developing a common European approach to employment and social policy, in DG EMPL. He also obtained agreement on this notion with the directorate general of economic and financial affairs (DG ECFIN), facilitated by his own background as finance minister. He worked closely with Odile Quintin and Jerome Vignon, long-term high-level civil servants in DG EMPL who supported Larsson's efforts in developing the institutional base for the EES. Under the directorship of Allan Larsson, in 1996 an employment committee comprising member state representatives from ministries of labour, and an employment indicator sub-committee with technical experts to agree on EU indicators for employment policy, was created (de la Porte 2008).

Jean-Claude Juncker, Prime Minister of Luxembourg and President of the European Council (during the second half of 1997), and Wim Kok, a Dutch social-democratic politician, were key political entrepreneurs that gained consensus among member states, enabled by a social-democratic majority among EU member states, on the EES (Interview 2017a). This facilitated agreement on the 'Employment Title' in the Amsterdam Treaty (1997), which provided a legal base for EU activity in employment policy. Employment policy was addressed by the EU through policy coordination to support member states in modernising their employment policies. The aims of EES were agreed at a summit initiated by Juncker at the end of 1997. The policies agreed in the EES supported the monetarist paradigm defining the EMU, favouring labour market flexibility, but were more comprehensive, including policies related to areas such as work-life balance and life-long learning, which are also central in SI (de la Porte 2011). 
Following this, the Commission, with the involvement of intellectual entrepreneurs, aimed to develop EU policy for social inclusion and social protection. The Commission, particularly Odile Quintin, engaged in preparatory work. Concerning social protection, Maurizio Ferrera, Anton Hemerijck, and Martin Rhodes, as intellectual entrepreneurs, prepared a publication for the Portuguese Presidency in the first half of 2000. The volume was on the future of the welfare states, calling for recalibration, rather than retrenchment, of social and employment policies (Ferrera et al. 2000). The high-level report had a strong impact on the policy framework that was being developed during the Portuguese Presidency of the European Council in 2000.

During the Portuguese Presidency of the European Council in 2000, Antonio Guterres, then prime minister, and Maria Rodrigues, his advisor, engaged as political entrepreneurs in brokering and persuasion on a common EU social policy, with ideas and knowledge from the report on the future of welfare states. Guterres and Rodrigues wanted social policy to be on an equal footing with economic and employment policy. To mark this, they launched, for the first time, a Spring summit, where the economic and social ministers were to meet to discuss and agree on the EU's socioeconomic strategy. At the first summit in Lisbon, the social inclusion process was launched and a statistical database - EU Statistics on Income and Living Conditions (EU-SILC) - was developed in parallel. This summit has continued since then on an annual basis. Formally (legally), the Ecofin Council had most weight in the Council, but politically - supported by a strong representation of social democratic governments in the Council - the employment and social affairs council had considerable weight at the time. A social protection committee and an indicators sub-group were created to support the social inclusion and social protection processes, similar to the committees established to work with the EES (de la Porte 2008). The political momentum in support of economic growth with strong social protection continued for several years. The Belgian minister of social affairs at the time, Frank Vandenbroucke, was keen on strengthening social protection policy at EU level during the Belgian presidency. Thus, in 2001, he commissioned Gøsta Esping-Andersen, an intellectual entrepreneur, to write a report about a new welfare architecture for Europe. It was 
published as a book advocating SI, especially focusing on investing in children from a young age (Esping-Andersen et al. 2002). The academic work by Esping-Andersen was influential because it reenforced Larsson's idea of 'social protection as a productive factor', but with more evidence, as well as policy recommendations on how to reform social protection and develop SI.

Political and bureaucratic entrepreneurs in the Commission and the Council were key movers in issue-framing, institutional alignment, and consensus-building for EU coordination in employment policy and in social inclusion policy. Intellectual entrepreneurs provided research-based input to the debate. The institutional base then used by SI policies - issue-specific committees and technical subcommittees, objectives, legal and/or political commitment, indicators - was created during stage 1 .

\section{Stage 2: 2004-2010: Policy and institutional drift}

Stage 2 resulted in institutional and policy drift (that is, altered effect of an institution due to changed circumstances) of the aims related to human capabilities in the EES and to the rights-based and anti-poverty aims of the social inclusion OMC. The political context among member states changed in 2004 in conjunction with the eastward enlargement of the EU. The discourse on stable economic growth, coupled with comprehensive employment and social policy, was replaced with concerns about low growth and the social impact of enlargement in the member states Attention to the social dimension of Europe was no longer central because the left-leaning political parties in the Council had lost ground and the Commission had become more centre-right in its orientation.

André Sapir, an intellectual entrepreneur, contributed to shifting the political debate at that time. The Sapir Reports 1 and 2 emphasised the need to strengthen competitiveness (Sapir 2003). This issue-framing resonated well with member state political priorities at the time. The focus on competitiveness in the Sapir reports is reflected in the report that fed into the assessment of the Lisbon strategy in 2004/5. The 'Jobs, jobs, jobs', report initiated by Wim Kok, a political entrepreneur who 
had also been a pivotal figure in stage 1, altered the debate from growth, employment, and social cohesion towards competitiveness, growth, and jobs. It recommended that the link between economic and employment policies (EMU coordination and the EES) be strengthened, while social inclusion OMC was to continue alongside, but without the same political weight. These changes represent policy drift concerning the social dimension of the EU, which was endorsed by member states during the mid-term review of the Lisbon Strategy in 2005.

Following this, Barrosso planned to further revise the Lisbon Strategy in his second term, including centralisation of all coordination procedures (Interview 2017b). Furthermore, the centreright political majority among member states in the European Council and in the European Parliament were favourable to this agenda (Interview 2017c). Following the financial crisis of 2008, the economies of the periphery countries suffered, leading to sovereign debt crises whereby these countries were at risk of not being able to pay back their public debt without financial aid. Thus, when the second Barroso Commission took office, in 2009, the main issue on the EU agenda was regaining stability in the Eurozone area. The emphasis at EU level was on fiscal consolidation, to contain the effects of the crisis in the Eurozone and to prevent sovereign debt crises in the peripheral economies. At the same time, the plans already made for revising the Lisbon Strategy were pursued. Preparations for Europe 2020, which was to narrow the focus of the EES and OMCs to better support competitiveness and jobs, were already underway.

Laszlo Andor, who became commissioner for employment and social affairs under the Barroso Commission in 2009, wanted to move beyond the fiscal consolidation agenda that was dominant at the time. When he entered office, most of Europe 2020 had already been planned, although the relative weight of employment and social policy had not been settled. Andor was a key political entrepreneur who wanted to enhance the EU's attention to social policy. He worked on maintaining focus on the poverty issue. He engaged in consensus-building, first in the Commission, where DG ECFIN and the Secreteriat-General SECGEN had to be convinced, and then in the Council. The Commission accepted the anti-poverty policy of Europe 2020 because it built on the existing 
institutional framework. The Commission even accepted a new anti-poverty aim: to reduce the number of people at risk of poverty by 20 million by 2020. Following consensus-building by Andor, the member states reluctantly endorsed the anti-poverty policy and numerical aim. It was endorsed only because it was lightly institutionalised and involved a weak core benchmark (reducing poverty across the EU by 20 million persons by 2020). Employment policy, including a benchmark to reach a 75 per cent employment rate by 2020 , was consistent with the EU's growth strategy. Both aims were endorsed in 2010 as key pillars of the 'Europe 2020' strategy (Interview 2017a; 2017d). However, by the time Europe 2020 was adopted it had a low status politically, as it had mostly been developed prior to the financial crisis.

Europe 2020 was integrated into the centralised European Semester governance procedure. With the European Semester, DG ECFIN's role for stable finances and consolidation was strengthened legally, and also in terms of staffing; thus, there was virtually no room for social policy initiatives. Significant dossiers, such as labour markets, were shifted to DG ECFIN from DG EMPL. This signified that the aims for employment rates and flexibilisation, linked closely to the EMU, were prioritised, whereas quality in work and quality learning were de-emphasised (Interview 2017b; 2017c; 2017d; 2017e).

The institutionalisation of Europe 2020 and the European Semester were well underway and virtually decided when Andor took office. His influence on EU social initiatives was limited during this time. In the following period, Andor wanted a stronger a vision for social policy during the Eurozone crisis. He became familiar with key academics involved in the SI debate and, in parallel, envisaged the development of a European unemployment insurance system (Interview 2017b; 2017d).

\section{Stage 3: 2011-2013: The SI 'moment'}


Stage 3 consists of the adoption of SI policy, comprising investment in human capital throughout the life-course, in line with the intellectual conceptualisation about SI, but also other initiatives, such as anti-poverty policy. EU SI represents an instance of institutional displacement, whereby changes occur through the rediscovery of previously suppressed or suspended alternatives. Throughout this stage, various intellectual, political, and bureaucratic entrepreneurs mobilised in issue-framing, institutional alignment, and consensus-building on an EU SI policy. Numerous academic publications emphasised a life-course perspective of learning and skills development, highlighting the need to develop cognitive capabilities in early childhood, and on updating skills throughout the life-course (Morel et al. 2012). Building on this knowledge, intellectual entrepreneurs were first-movers in issueframing of EU SI policy. In 2011, Bruno Palier, Frank Vandenbroucke, and Anton Hemerijck wrote an opinion paper, entitled 'The EU needs a Social Investment Pact', intended to influence policymakers (Vandenbroucke et al. 2011). These three academics were also very active in advocating SI as a policy frame in the European Commission and in the European Parliament. Hemerijck presented the 'SI Pact' to the European Parliament that debated the issue and later adopted a resolution on this topic (European Parliament 2013).

Andor appointed high-level staff in DG EMPL in order enable progress with his social policy ambitions. In 2011, he appointed Lieve Fransen, a central bureaucratic entrepreneur in framing and adapting SI to the Commission context, as director of social policy and Europe 2020. She became leader of the ad hoc SI expert group, to which she recruited various academics, including Vandenbroucke and Ferrera (European Commission 2017a). Fransen has been characterised as Andor's 'right hand' in the issue-framing of SI in the Commission. She chaired the meetings of the SI Expert Group and set the agenda, with a clear ambition to reach consensus on a strong narrative about social investment, accompanied by indicators. Fransen hoped SI would contribute to adding a social dimension to the European Semester, like the EES and OMC in inclusion had added a strong social dimension to the Lisbon Strategy (Interview, 2017f; 2017g; Social Investment Expert Group 2013a; 2013b). 
The SI Expert Group developed an SI narrative, strongly influenced by the ideas of intellectuals via the SI expert group and from the SI Pact (Vandenbroucke et al., 2011) More specifically, the bureaucratic leadership of Fransen enabled a transposition of knowledge from academics to the European Commission. The SIP was adopted in February 2013. The central pillar of this was a communication on SI stressing ' $(\ldots)$ the need to invest in human capital throughout life and ensure adequate livelihoods'(European Commission 2013) ${ }^{\text {iii }}$. It identified policies with a higher SI orientation, including: policies targeted at children, active labour market policies, education, training and lifelong education, housing support, rehabilitation, healthcare and long-term care services. These aims were not new, but SI as an overarching framework was novel compared to the EES and the social inclusion OMCs. The SI communication remarried the EES and the social inclusion OMC, which had decoupled in the mid-term revision of the Lisbon Strategy in stage 2. SI was framed as a complement to social protection (Interview, 2017f; 2017g; 2017h; Social Investment Expert Group 2013a). This countered fears among some academics that SI was merely a neo-liberal policy frame in disguise (Nolan 2013). One expert suggested that SI represented 'a new "acquis" on the intellectual level' (Interview 2017g), while another assessed that the SIP aimed to make the European Semester 'more likeable' (Interview 2017f). Compared to the EES and social inclusion $\mathrm{OMC}$ - the antecedents to EU SI - there is more emphasis on starting investment in human capital very early. Indeed, the Commission recommendation that is part of the SIP focuses on children's rights and investment in children (Interview 2017g). The life-course perspective that is the backbone of the SI approach developed by the EU places special emphasis on SI directed towards individuals and women, rather than families (Social Investment Expert Group 2013a).

Following issue-framing of SI and decision-making that resulted in the SIP, the debate in the SI expert group turned to indicators, measurement and implementation of SI. Fransen, as the key bureaucratic entrepreneur, hoped SI indicators would be adopted so that DG ECFIN would take account of SI in the European Semester. In the SI expert group there was extensive debate about the efficiency and effectiveness of SI and welfare states in general, but it was not conclusive. The debate 
on indicators was rather limited (Interview 2017g; 2017h , 2017i; Social Investment Expert Group 2013b). In terms of identifying core quantitative indicators, the group fell short of its ambitions. Our interviewees noted that while the immediate explanation is technical - that is, there are no indicators to assess SI - the underlying reason is political ${ }^{\text {iv }}$ (Interview 2017f, Social Investment Expert Group 2013a; 2013b).

One interviewee concluded that: 'It was not the right time. Member states were not open to EU recommendations related to SI, such as investing more in child-care, and thus, the potential of SI was not fully exploited' (Interview, 2017e). SI was largely ignored among member states, which contrasts with the high political engagement among member states with EU social policy during stages 1 and 2 (Ferrera 2016).

Since the political momentum for EU SI was not strong, it was weakly institutionalised. SIP is loosely integrated in the European Semester and the structural funds, it does not stipulate precise targets, and it does not have a strong legal base to require changes in Member States. Analytically, we see a limited SI 'moment', rather than a shift to a strongly institutionalised SI policy. An expert close to the SI working group said that 'Andor should be credited for coming up with SI in the context of a neo-liberal/right-wing Commission', but that at the time ' ...the EU was more strongly committed to being a fiscal consolidation master than a SI cheerleader' (Interview 2017h). After the SI moment that culminated in the SI communication and other documents, in the SIP it became 'lost in translation' in the shift from ideational consensus to indicators and political commitment. The other social policy issue which Andor had mobilized for as political entrepreneur, a European Unemployment Insurance system, stopped in the tracks before decision-making, due to the redistributive implications for member states. Our findings regarding this stage imply that even if the combined issue-framing and consensus-building of intellectual, bureaucratic and political entrepreneurs lead to activity, a decision to endorse a policy, and some output, if the political context is not favourable, the possibilities for significant policy change are limited. 


\section{Stage 4: 2014-2018: From SI to the European pillar of social rights}

After Andor's term in the Commission terminated, there were no strong SI entrepreneurs in the Commission. The SI working group was dissolved, Fransen left the Commission, and the main intellectual entrepreneurs of SI were no longer active in the EU arena. The social agenda of the new Juncker Commission in 2014 focused on strengthening social rights (Interview 2017a; 2017d; 2017j). Stage 4 starts with the Commission preparing this new agenda, the EPSR.

At the time of writing, SI policies, rooted back in the EES and the social OMCs, and extended with the SI communication, are integrated in discussions on the emergent pillar of social rights. Policy priorities of the EPSR include 'equal access to labour markets and skills development, tackling poverty and fair working conditions' (European Commission 2017b: 27). The European Parliament report on the EPSR concludes that it '(...) will not deliver without SI, especially in available and affordable high-quality infrastructure for caring for children and other dependent persons and also measures to combat discrimination between women and men' (European Parliament, 2016: para 37). SI is integrated throughout the report, and is framed as a productive factor, following on from the initial framing by Allan Larsson in the 1990s, but including a broader range of areas (Interview $2017 \mathrm{~g})$.

The presence of SI can be partially explained by the fact that some of the central individuals involved in the EPSR have been key entrepreneurs in the previous moments of institutionalisation of EU social policy. Fransen, now in a think-tank, reiterates and builds on the intellectual framing of SI (Dheret and Fransen 2017). Rodrigues, a key political entrepreneur behind the Lisbon Strategy and the social inclusion OMC, has mobilised for the EPSR, and with it SI, in the European Parliament (European Parliament 2016). Allan Larsson, a political and bureaucratic entrepreneur involved in the EES, is advising the European Commission on the pillar of social rights. While the pillar has many interesting social policy initiatives, the specification of instruments for SI is weak. Thus far, the result 
is not conclusive, but the presence of key entrepreneurs from the previous stages suggests that momentum for SI may at the very least be maintained, and perhaps even strengthened.

\section{CONCLUDING DISCUSSION}

This contribution has considered, through an actor-based historical institutionalist analysis, why and how SI emerged in EU social policy governance in the aftermath of the economic and financial crisis. While SI has been described as a game changer in EU social policy, we have shown that it is more accurate to see it as a 'moment' in a longer time period of gradual institutional change. The 'SI moment' materialised due to the combined activity of intellectual, bureaucratic, and political entrepreneurs. It represents the partial reactivation of latent initiatives from the late 1990s and early 2000s, but providing a broad policy narrative - in fact broader than the SI narrative among academics that focuses on skills development throughout the life course - to join separate processes.

Building on the literature on policy entrepreneurs, this study shows that three categories of entrepreneurs - intellectual, bureaucratic, and political - are movers in gradual institutional change. The findings of the study suggest that historical institutionalists should focus on entrepreneurs even more than they currently do. These actors engage in a variety of issue-framing, institutional alignment, and consensus-building activities. Intellectual actors, mobilising knowledge for problemdefinition and solutions, are crucial in the early part of the policy cycle. They are important in exposing their ideas - and framing policy problems and solutions - over a longer time period, in relevant bureaucratic and political institutions. Bureaucratic entrepreneurs are crucial in setting up and managing expert groups, drawing in intellectual entrepreneurs, and transposing this knowledge to the relevant context through institutional alignment. Finally, political entrepreneurs are decisive in consensus-building related to the decision on a policy. Entrepreneurs engage in issue framing and consensus-building during a limited period of time, a window of opportunity, when their activity is likely to result in a decision, which may comprise institutional change. In addition to strong 
entrepreneurial activity during a short period of time, the analysis in this contribution shows that the continuous involvement of some actors in policy shaping is crucial, particularly for areas with a weak legal base, such as EU SI. Some of the entrepreneurs that supported EU social governance in the late 1990s continued to be involved in the EU arena for two decades, although not necessarily as entrepreneurs.

However, this study also suggests that political conditions are a crucial intervening variable that shapes the extent of institutional change. In stage 3 of our case study, political conditions in the Commission, with a very strong and reluctant DG ECFIN, were a hindrance to a more robust lasting presence of SI at EU level. The result is therefore that EU SI is weakly integrated in the European Semester, where economic and public policy is centrally coordinated at EU level. Furthermore, member states, with the presence of populist parties from the left and the right of the political spectrum, were not keen on accepting EU advice on SI. Compared to previous stages, stage 3 is marked by a lack of strongly engaged national politicians willing to transpose EU SI to national contexts. This contrasts with the strong political momentum from member states during stages 1 and 2, when the EES, OMC inclusion, and Lisbon strategy were debated among prominent politicians in some member states. Following counter-factual reasoning, if the 'SI moment' had not occurred then the policies in the EES and OMC inclusion would probably have remained as background ideas, rather than resurfacing during stage 3. EU SI did enable the various policy initiatives to be joined into one overarching policy narrative. Furthermore, although the political agenda has changed to an EPSR during stage 4, the continued presence of actors that made significant contributions in previous stages, although in different roles, may enable integration of EU SI into the EPSR. 
Caroline de la Porte is Professor MSO of European and comparative welfare governance and policy and Head of the Department of Business and Politics, Copenhagen Business School.

David Natali is Professor of Comparative and EU Politics at the S. Anna School of Advanced Studies of Pisa, and associate researcher at the European Social Observatory of Brussels.

Address for correspondence: Caroline de la Porte, email: cdlp.dbp@cbs.dk; postal address, Copenhagen Business School, Department of Business and Politics, Steen Blichers Vej 22, DK-2000 Frederiksberg

\section{References}

Armingeon, K. and Baccaro, L. (2012) Political economy of the sovereign debt crisis: the limits of the internal devaluation, Industrial Law Journal, 41(3): 254-275.

Crespy, A. and Menz, G. (2015) 'Commission entrepreneurship and the debasing of Social Europe before and after the Eurocrisis', Journal of Common Market Studies, 53(4): 753-68.

de la Porte, C. (2008), “The Evolution and Influence of the Open Method of Coordination: The Cases of Employment and Social Inclusion" Phd Thesis, Social and Political Science Department, European University Institute, Florence, Italy, 296 pp.

de la Porte, C. (2011), "Principal-agent theory and the Open Method of Co-ordination: the case of the EES”, Journal of European Public Policy, 18(4): 485-503 
de la Porte, C. and Heins, E. (2015) “A new era of European Integration? Governance of labour market and social policy since the sovereign debt crisis" Comparative European Politics, 39: 13(1): $8-28$.

Dheret, C. and L. Fransen (2017) 'Social Investment first! A precondition for a modern Social Europe', Issue paper no. 82, European Policy Center, March 2017.

Esping-Andersen, G. (eds.) (2002), Why we Need a new Welfare State. Oxford: Oxford University Press.

European Commission (2013) Towards social investment for growth and cohesion - Including implementing the European Social Funds 2014-2020, Brussels, COM(2013), 83 final.

European Commission (2017a) Expert Group on Social Investment for Growth and Cohesion, downloaded 17 January 2017, http://ec.europa.eu/transparency/regexpert/index.cfm?do=groupDetail.groupDetail\&groupID=2819.

European Commission (2017b) The European Pillar of Social Rights: Going Forward Together, draft programme for meeting on 23 January 2017.

European Parliament (2013), Resolution of 12 June 2013 on the Commission Communication 'Towards Social Investment for Growth and Cohesion — including implementing the European Social Fund 2014-2020' (2013/2607(RSP)) 
European Parliament (2016) Report on a European Pillar of Social Rights, 20 December, Employment and social affairs committee, ref. 2016/2095.

European Union (EU) (2016) Standard Eurobarometer 86, Public Opinion in the European Union: First Results, Brussels.

Ferrera, M. (2016) 'Impatient politics and social investment: the EU as "policy facilitator"', Journal of European Public Policy, DOI 10.1080/13501763.2016.1189451.

Ferrera, M., Hemerijck, A. and Rhodes, M. (2000) The Future of Social Europe, Recasting Work and Welfare in the New Economy. Oeiras: Celta Editora.

Hall, P.A. (2008) 'Systematic Process Analysis: What it is and how to use it', European Political Science, 7(3): 304-17.

Heclo, H. (1974) Modern Social Politics in Britain and Sweden: From Relief to Income Maintenance. New Haven, CT: Yale University Press.

Hemerijck (2015) 'The Quiet Paradigm Revolution of Social Investment', Social Politics, 22(2): 242256.

Interview (2017a), official, DG EMPL, 5 May (Bureaucrat).

Interview (2017b), former member of Cabinet of Laszlo Andor, DG EMPL, Lukas Vesely, 4 May (Political). 
Interview (2017c), official, DG ECFIN, 4 May (Bureaucrat).

Interview (2017d), member of Cabinet of Jean-Claude Juncker, 5 May (Political).

Interview (2017e), Laszlo Andor, 22 May (Political Entrepreneur).

Interview (2017f) former academic member of ad-hoc Social Investment Expert Group (2017), 26 January (Academic Entrepreneur)

Interview (2017g) former academic member of ad-hoc Social Investment Expert Group, 29 January (Academic Entrepreneur).

Interview (2017h) former academic member of ad-hoc Social Investment Expert Group , 10 January (Academic Entrepreneur).

Interview (2017i) former academic member of ad-hoc Social Investment Expert Group , 5 April (Academic Entrepreneur).

Interview (2017j) Lieve Fransen, former director responsible for Europe 2020 in DirectorateGeneral Employment, Social Affairs and Inclusion of the European Commission, 10 May (Bureaucratic Entrepreneur).

Kingdon, J.W. (1995) Agendas, Alternatives and Public Policies. New York: Harper Collins.

Mahoney, J. and Thelen, K. (eds.) (2010) Explaining Institutional Change: Agency, Ambiguity and Power. Cambridge: Cambridge University Press. 
Mintrom, M. and Norman, P. (2009) 'Policy entrepreneurship and policy change', The Policy Studies Journal, 39(4): 649-667.

Morel, N., Palier, B. and Palme, J. (2012) 'Beyond the Welfare State As We Knew It?', in N. Morel, B. Palier and J. Palme (eds.), Towards a Social Investment Welfare State? Ideas, Policies and Challenges. Bristol: Policy Press, pp. 1-30.

Nolan, B. (2013), 'What use is social investment?', Journal of European Social Policy, 23(5): 459468.

Pierson, P. (1996) 'The path to European integration. A historical institutionalist analysis', Comparative Political Studies, 29(2): 123-163.

Sapir, A. (2003) An Agenda for a Growing Europe: Making the EU System Deliver, Report of an Independent High Level Group established at the initiative of the President of the European Commission.

Scharpf, F. (2013) 'Monetary Union, Fiscal Crisis and the Disabling of Democratic Accountability', in A. Schäfer and W. Streeck (eds.), Politics in the Age of Austerity. Cambridge: Polity Press, pp. $108-142$.

Social Investment Expert Group (2013a) Minutes of 06/03/2013.

Social Investment Expert Group (2013b) Minutes of 18/06/2013. 
Stiller, S. (2010) Ideational Leadership in German Welfare State Reform. How Politicians and Policy Ideas Transform Resilient Institutions. Amsterdam, Amsterdam University Press.

Streeck, W. and K. Thelen (2005) Beyond Continuity: Institutional Change in Advanced Political Economies. Oxford: Oxford University Press.

Trampusch, C. and Palier, B. (2016) 'Between X and Y: how process tracing contributes to opening the black box of causality', New Political Economy, 1-17, DOI: 10.1080/13563467.2015.1134465

Vandenbroucke, F., A. Hemerijck and B. Palier (2011) The EU Needs a Social Investment Pact, OSE Opinion paper no. 5, May.

Verdun, A. (2015) 'A historical institutionalist explanation of the EU's responses to the euro area financial crisis', Journal of European Public Policy, 22(2): 219-237.

Zeitlin, J. and Vanhercke, B. (2017) 'Socializing the European Semester: EU social and economic policy co-ordination in crisis and beyond', Journal of European Public Policy, DOI: $10.1080 / 13501763.2017 .1363269$

\footnotetext{
${ }^{i}$ We would like to thank three anonymous referees, the participants of the October 2017 Work-inprogress seminar of the Department of Business and Politics, CBS and Margarita Leon for helpful comments on earlier versions of this paper.

i While entrepreneurs among stakeholders may also be relevant to consider, they rarely have a formal role in the policy process. This differentiates them from the other actors under examination in this paper.
} 
iii The SIP also included a Recommendation on 'Investing in Children: Breaking the cycle of disadvantage' and a series of Staff Working Documents.

iv Various international organisations' work on indicators that could be considered to assess some aspects of SI. However, DG ECFIN and member states are reluctant to adopt and use such indicators at EU level, while DG EMPL is favourable to such indicators. 